This is the version of the article accepted for publication in Tourism Management published by Elsevier: https://doi.org/10.1016/j.tourman.2018.10.001

Accepted version downloaded from SOAS Research Online: http://eprints.soas.ac.uk/29927

This was published under: https://creativecommons.org/licenses/by-nc-nd/2.0/uk/

\title{
The Exotic Veil: Managing tourist perceptions of national history and statehood in Oman
}

\section{Senija Causevica and Mark Neal}

\begin{abstract}
This article explores how and why some national governments seek to manage and control tourist-oriented narratives about historic sites and artefacts. Discussing ethnographic research among tour guides, tourists and government representatives in Oman, the paper reveals how the country's historic sites are overwhelmingly staged and presented without historical information. Instead, history is displaced by sanitised presentations of cultural heritage, the display of which draws an "exotic veil", crafted to enchant and deflect tourist attention from politically sensitive historical events and legacies. The study examines reasons for this policy, and its implications for tourists and those working in the tourism industry. Many of Oman's tour guides and site representatives are from marginalised groupings, experiencing inequalities due to historical family, tribal and former slave status. The statesustained exotic veil on history means that such workers are obliged to collude in denying the historical reasons for their own experiences of injustice and inequality.
\end{abstract}

Key words: Orientalism, Oman, cultural heritage, tour guides, museums, political instability, exotic veil 


\section{Introduction}

Zeppell and Hall (1991) observed how some national governments and their agencies seek to control how history is presented to tourists. The ways in which they do this, and the degrees to which they do this, are diverse. In some countries, the presentation of history is politically sensitive, ensuring that certain events are excluded from tourist narratives altogether. In other cases, political/ moral outrages such as the Holocaust or the Srebrenica genocide become the focus of tourist interest, with state-sanctioned narratives about such events constituting a key interactive feature of the visitor experience (Podoshen, 2017; Naef \& Ploner, 2016). As Holguin (2005) observed, in Spain, the Franco era is rarely discussed in commercial tourist discourse, and remains obscured by state authorities. Meanwhile, Rivera (2008) examined how and why Croatia obfuscates its socialist Yugoslav past (1945-1991) through expounding nationalist histories that celebrate its pre-World War II "golden ages" (Goulding \& Domic, 2009). The Croatian state and its agencies thereby represent the country as being untainted by Yugoslavia, with its Slavic roots (Rivera, 2008). Destination marketing place representations are thus socially-constructed and sustained for particular purposes by particular groups. They are clearly not value free expressions of place identity, but, to varying degrees, are influenced, managed and sustained by political elites (Pritchard \& Morgan, 2001, p. 177; Ateljevic \& Doorne, 2002).

Examining the political nature of historical narratives in tourism raises interesting analytical issues. It highlights the importance to political elites of presenting a coherent narrative of statehood, and its legitimacy, to visitors. It raises the question of why some national and regional governments seek to control historical narratives, and for what political purposes. It reveals contradictions between academic and popular historical narratives, and those presented by the state and its agencies; and it highlights the role of historical narrative in the experience of visitors.

This paper explores these issues by focusing on the staging and presentation of historical sites and artefacts for foreign visitors to the Sultanate of Oman. Doing so reveals how governmentmanaged tourism policies, facilities and activities artfully present statehood in ways that shield visitors from the realities of Oman's turbulent political history. This can be understood as the state imposing an "exotic veil" on history - a policy of requiring those involved in the tourism industry to self-Orientalise (Feighery, 2012), to stage and enact a 
form of authenticity intended to enchant visitors and convince them that they are experiencing the "real" country and its "exotic" culture, while deflecting attention from deepseated inequalities and political controversies (MacCannell, 1973, 1976; Cohen, 1988). Drawing on an ethnographic research project, the study explores various aspects of this exotic veil over history: the reasons for its imposition, and how it is managed; its performative realisation by institutions, tour guides and other workers in the tourism and hospitality sectors; its experiential implications for tourists; and its political and existential significance for different sectors of Omani society.

The exotic veil involves the sensory manipulation of tourist perceptions in order to enchant and obscure. Berelson and Steiner $(1964$, p. 8) defined perception as the "complex process by which people select, organise, and interpret sensory stimulation into a meaningful and coherent picture of the world." Staging Orientalised tourism encounters involves influencing visitors' perceptions through music, text, video presentations, perfumes/ odours, lighting and sound. Equally important in this Orientalisation is the exclusion of certain contradictory sights, sounds, smells and information, such as: visions of poverty, disability or modernity; bad smells; loud noise; and, crucially, the exclusion of historical and/ or political realities. The shaping of tourist perceptions involves much more than a dyadic relationship between stager and perceiver, but involves the accumulated experience, knowledge and expectations of the visitor, and prior and emerging discourses and narratives among fellow tourists.

In an earlier examination of tourism video materials, Feighery (2012, p. 275) highlighted the political nature of Oman's official touristic narratives, arguing that they present the country as,

"unified, stable, traditional, and welcoming, while simultaneously commodifying its heritage, culture, and natural environment in support of government-sponsored tourism developments... In that process of economic and social development and nation building, the Omani regime has interpolated a diversity of tribal peoples and cultures into an Omani identity. Thus, the film can be viewed as contributing to the current administration's efforts to maintain legitimacy over the entire territory and peoples of Oman." 
Following on from Feighery's (2012) observations, this paper explores the treatment of history in Oman's presentation of historical sites and artefacts to tourists, by seeking answers to the following questions:

1. How does the Omani government, and its agencies, manage perceptions of history among tourists in Oman?

2. What explanatory and contextual narratives are provided to tourists visiting historical sites and artefacts?

3. How do tourists perceive and understand these narratives, and integrate them into their experiences of visiting Oman?

4. How do tourism workers perceive and understand these narratives, and what do they think about tourists integrating such narratives into their experiences of visiting Oman?

The remainder of this paper seeks to answer these questions, and to explore the implications of the findings for ongoing debates about tourism management, authenticity and selfOrientalisation (Wei, Qian \& Sun, 2018; Ram, Björk, \& Weidenfeld, 2016).

\section{Theoretical orientation}

Said (1978) examined the constitution of the "West" in relation to an externalised "Eastern", Islamic "other", and highlighted modes of representation of an imagined, discursively constructed place called the "Orient" or the "East" at specific junctures in the history of those cultures that are loosely termed "the West". Said's (1978) concept of Orientalism frames Western definitions of non-European cultures as exotic, sensual, enchanting and alluring. Orientalising exaggerates difference at the expense of shared humanity, resulting in a Derridan alterity, presenting non-Western cultures as being imbued with exotic otherness to be authentically experienced and consumed (Derrida, 1978). Bryce (2012) stressed the power of such binary representations as "West/East", "Europe/Islam" and "modernity/history" in commercial place promotion, arguing that tourism often sustains political structures and inequalities, which have subjective, spatial and political consequences for the understanding of those places; and these cannot be separated from tourism's invitation to the pleasurable consumption of "difference". Observing that many tourists seek to situate themselves in hegemonic notions of the past, Kerrigan, Shivanandan and Hede (2012) examined tourism 
marketing of India, which featured familiar colonial images when targeting British tourists. As Bryce, MacLaren and O'Gorman (2013) observe, this is by no means a one-way process, as indigenous destination marketers recognise the commercial power of such motifs, and feature them accordingly.

Feighery (2012) recognised the pressure on Middle Eastern countries, and those involved in providing tourist services in the region, to self-Orientalise in order to present themselves as attractive and exotic to tourists. Destination marketers have responded to this trope accordingly. As Cohen (1985) observed, the intention of such presentations of local culture is to provide tourists with a self-satisfying sense that they are encountering real, authentic, traditional culture - which some visitors find more satisfying and gratifying than the "fakeries" and "hedonisms" of mass tourism. This, of course, can lead to uncomfortable contradictions between locals and visitors. Locals may find the playing out of traditions at odds with their own modern lived experience, while they objectify and commodify key aspects of their traditions for touristic consumption, and exaggerate, simplify or pervert the actual culture within which they live (Korpela, 2010). However, locals and state agencies are economically incentivised to self-Orientalise (Feighery, 2012) and weave an intoxicating allure, which encourages return visits and the buying of local craftwork; and which enhances the overall popularity of the sites. Many tourists visit these spaces and cultures not to experience modernities and post-modernities resonant with their own cultures, but to immerse themselves in other-worldliness, and thereby experience enchantment and excitement - a feeling of existential adventure and spiritual enrichment from supposed experience of "the other", and immersion in "otherness" (Bloch, 2017).

What is less explored in debates about authenticity and tourism is how self-Orientalisation can be used to obscure politically sensitive histories. This process can be usefully viewed as the social construction and sustaining of an "exotic veil" - the sensory crafting of selected aspects of the country's cultural heritage to enchant visitors, and obscure history and political conflicts from them (see, for instance, Kerrigan, Shivanandan, \& Hede, 2012; Johnson, 2010; Bryce, MacLaren, \& O'Gorman, 2013). Studying these issues in Oman gives us the opportunity to examine the reasons for, and realities of, the state-sanctioned veil on history, and to appreciate its experiential and political consequences for visitors, locals and political elites. It thus allows us critically to explore and evaluate the use and usefulness of theoretical conceptions of authenticity and self-Orientalisation in Middle Eastern tourism. 


\section{Why does Omani history need to be hidden, or veiled, from tourists?}

Three great schisms have structured Omani society and its political history. The first is the physical barrier of the Hajar mountains, which have long divided the tribes of Oman into those of the coast (Muscat and the Batinah region) and the interior (the Dakhiliyah region) (see Figure 1). Throughout the country's history, there have been periodic tensions between the Omani Interior, generally ruled by elected Ibadi Imams, and the coastal Sultanate of Muscat (see Appendix 1). Indeed, before 1970, the official name of the country was "Muscat and Oman". Muscat (Muttrah) harbour was the possession of successive foreign powers, such as the Portuguese, Persian and Ottoman empires. Each attempted to impose order on the religiously and ethnically divided population, which often exacerbated tensions with the Interior.

Figure $1 \& 2$ about here

The second great schism is the division of the numerous Omani Arab tribes into two metatribal affiliations: the Azd tribes, which constitute a branch of the Kahlani tribes of the south, which had migrated to Oman from what is now Yemen in search of sustainable water resources; and the Adnani tribes of the north, which claimed lineage to Prophet Mohammed, and raised the ruling tribes of the pre-modern and modern ages, i.e. the Nabhani (1154-1624), the Yaruba (1624-1742) and, finally, the Bu Said dynasty, which rules today.

A third schism is more complex, involving social, political and economic differences sustained in Oman's cultural diversity. Three major ethnic minorities in Oman have national citizenship. These include Omanis not of Arab origins, such as the Belushi and Zajali, who migrated from Baluchistan on the border between Pakistan and Iran over the past three to four hundred years. Despite their long presence in Oman, many remain fluent in Farsi or Urdu dialects. The second ethnic group are the Lawati, who migrated from the Sindh region of Pakistan over the centuries, and clustered around the trading hub of Muttrah harbour near Muscat. Lawatis are Shia, and retain their Khojki language (Valeri, 2010). A third ethnic minority grouping is made up of Zanzibaris, who migrated from former Omani territorial 
possessions of East Africa in the 1970s. Many had intermarried with indigenous Africans. Omani Zanzibari are mostly fluent in English and Swahili, and the first generation of returnees still struggle with communicating in Arabic (Valeri, 2009).

\section{Ibadism, empire and slavery}

Religiously, Omani history is rooted in its indigenous form of Islam, Ibadism, which, as Phillips (1971) observed, is foundational of Omani national identity. Politically, the country's history has been a story of prominent tribal dynasties - the Nabhani (1154-1624), the Yaruba (1624-1742) from the interior, and finally the Bu Saíd dynasty from the coast. The Nabhani dynasty ruled Oman until 1624, when, after a period of tribal warfare, it lost out in its struggles against the Yaruba. The victorious leader, Nasir bin Mursid bin Sultan al Yaruba, and his cousin and successor Sultan bin Saif al-Yaruba, consolidated the dynasty's power, freed the country's seaboard from Portuguese occupation, and united the tribes of the coast and the interior (Risso, 1989). The Yaruba dynasty furthered Oman's economic and political interests, acquiring former Portuguese colonies in East Africa - including Zanzibar. Through increasing command of these logistical routes Oman profited from trade in ivory, metals, cloves and slaves (Suzuki, 2017). From the mid-17 $7^{\text {th }}$ century, the Yaruba dynasty expanded the trading empire of Oman to key ports and vassal states in Zanzibar, Eastern Africa, the Western seaboard of India and modern-day Pakistan and Iran (notably Baluchistan). This logistical and trading network became what is commonly called, the "Omani Empire", feted in touristic narratives about the history of the country (Feighery, 2012).

The Bu Said dynasty ruled from 1749, when Imam Ahmed bin Said al Bu Said, Wali of Sohar, united Muscat and Oman and established what was recognisably a state. Later, during Sultan Said bin Sultan Al-Said's rule (1806-1856), the country consolidated economic and political hegemony over its East African colonies and Indian colonies, and increasingly profited from Zanzibar's role as a key hub in the slave trade from the African seaboard through the Indian Ocean and the Gulf. However, the British, the dominant naval power of the time, became increasingly active in intercepting and blocking the transportation of slaves along the Eastern seaboard of Africa, and between Zanzibar and Oman. This disrupted Omani trade, and the country went into steep economic decline. During the subsequent recession, many Omani families migrated to Zanzibar, and the population of Muscat fell dramatically between the 1850s and 1870s. The United Kingdom exploited Oman's weakened state to 
seize its overseas territories, and by 1890 Oman was an isolated and poor "failed state". This economic and demographic decline exacerbated conflict between the two key political blocsthe coast and the interior - and the country descended into an extended period of tribal warfare, which was suspended only temporarily by the signing of the Treaty of Seeb in 1913 (Risso, 1989).

Two major civil wars have taken place in the past sixty five years, and they continue to resonate today. The first was the Jebel al Akhdar war (1954-1959), where the tribes of the Dakhiliyah and Hajar mountain regions allied themselves with Saudi Arabia and rebelled against the Sultanate. In the destructive and protracted struggle that ensued, the Sultan, with British support, attempted to regain the Jebel al Akhdar region and unify the country again through force. However, the new Imam led a sporadic five-year rebellion against the Sultan's efforts to extend government control into the interior. The insurgents were finally defeated in 1959 with British help. The Sultan then terminated the Treaty of Seeb and eliminated the office of the Imam, who took refuge in Saudi Arabia. In the early 1960s, the Imam continued to agitate against the Sultan, and won political support from his Saudi hosts and other Arab governments for reinstatement of the Imamate. However, this alliance ended in the 1980s, as Sultan Qaboos consolidated his political hegemony over the interior region (Joyce, 1995).

The second major civil war was the Dhofar Rebellion (1962-1975) in which the Union of Soviet Socialist Republics (USSR) and the People's Republic of China (PRC) provided military and logistical support for North Yemeni communist insurgents allied with southern Omani tribes, who were involved in a military campaign to overthrow the Islamic Sultanate. Qaboos seized the throne in the midst of this conflict, and - with British support - he eventually suppressed the insurgents, re-established order, and set to work on unifying the country. The succession and subsequent success of Sultan Qaboos in military, economic, social and nation-building terms meant that his accession marks the beginning of what is officially called the "Renaissance" of the country (Phillips \& Hunt, 2017). A clear demarcation is thereby made in historical, political and economic discourse in Oman between the violent and impoverished time before his rule, and the period of political stability and prosperity after he took power. That notwithstanding, the bloody recent history of tribal conflict in Oman is remembered among the older generations in Oman; and the tectonic regional and tribal pressure-points persist to this day, though in diminished potency (Phillips \& Hunt, 2017; Valeri, 2009). 


\section{Current conditions}

When Sultan Qaboos took over an impoverished and violent country in 1970, he quickly set to developing the institutions of governance and state, and to building national unity. In promoting unity, the Sultan was - and is - celebrated as the marker between tribal chaos and paternalistic order (Valeri, 2009). The state-sponsored apotheosis of Sultan Qaboos means that his image is now everywhere - in hotel lobbies, municipal offices, on the sides of buildings and even painted on private automobiles. All institutions and political elites in Oman now actively promote Qaboos as the purveyor of unity and light. This hegemonic policy of idealising the Sultan has largely succeeded, and there is a widespread view among Omani citizens that the years prior to his rule were indeed dark ages, not to be discussed. For the institutionally-backed Sultanic order, the history of the time before the Renaissance remains politically problematic and threatening.

The Sultanic hegemony rests for its legitimacy on three things: birthright, societal order and the idea of liberal modernity. With the complex and politically skewed tribal system remaining deeply entrenched, and persisting as a potential source of disorder, history is problematic for the political elite as it involves blood feuds, wars, massacres and assassinations - of tribal victors and losers - and it exposes the persistent schism between the coastal and interior regions. Although the state constitution, drafted in 1996, marked the marginalisation of the political role of the tribe, particular tribes were able to retain their power (Valeri, 2009). Some tribes and families benefited from the unified Sultanate, while others lost out. Resentments at the inequitable distribution of oil rents still rankle, and do so at the collective level of the tribe. The pride and reputation of those tribes who opposed the Sultan have been undermined by his success.

Qaboos is promoted as being progressive, tolerant and forward-looking. Indeed, the Sultan's legitimacy rests in part on the idea of liberal modernity, even though Oman is an autocratic state. History is problematic here as well, as it reveals that the abominations of the slave trade were integral features of the "golden age" of the Sultanic Omani empire right up until the nineteenth century. Indeed, slavery persisted domestically after the international ban, and it was only officially abolished in Oman in 1971. The current population is made up of many former slave or client families - categorised as three classes, the mawali, khuddam and 
bayasira - and they continue to experience social exclusion and relative deprivation today (Al-Azri, 2013, p. 41).

With the economic need to diversify away from petrochemicals, and the aggressive promotion of tourism as an alternative source of national income, the country has faced the problematic question of how it should present its history to tourists. This is a doubly problematic issue in that many of the tourist attractions in the country are historical sites. In the 1970s, the Sultan decreed that the most significant and impressive of the forts and castles around the country should be rebuilt. The subsequent restoration programme has created world-class heritage-tourism capital; and one such site, Bahla castle, achieved World Heritage Site status in 1987 (UNESCO, 2018). Oman's forts now feature strongly in its tourist itineraries and promotional materials (see Feighery, 2012; Hegazy, 2014). This programme of redevelopment of the castles has undoubtedly been a factor in the increasing profile of Oman as a tourist destination (see Table 1, Appendix $2 \& 3$ for tourism arrivals and receipts).

Table 1 about here

The remainder of this paper examines the status and treatment of history in tourism in Oman, by examining how the country's problematic past is obscured in contradictory ways at historical sites, such as castles and museums. Through discussing an ethnographic study of these sites, and of the people interacting with them (tourists, guides, receptionists and decision-makers in relevant ministries), the analysis reveals how an exotic veil over history is now sustained through state-imposed self-Orientalisation, and the presentation of idealised and sanitised versions of cultural heritage.

\section{Research Orientation, Methodology and Data Analysis}

\section{Context}

One of the authors was working at a university in Oman, and had already lived in the country for five years. During this time, he had repeatedly visited historical sites, museums and forts 
all around the country. He had begun this process as a curious tourist, but through these visits soon developed a keen interest in the presentation of history at such sites. Tourist activities thus developed into a long-term study involving multiple visits to forts, museums, harbours and religious sites in Oman's regions of Dakhiliyah, Sharqiyah, Batinah, Zahirah and the city of Muscat (see Table 2 for the full list of the sites, and Figure 2 for the map). Through repeatedly visiting these places and talking to those at the sites, the author gained a familiarity with the locations and with visitors' perceptions and experiences of them (van der Duim, 2007). Increasingly, over the five year period, Omani friends and colleagues accompanied him to the sites and explained the history around them.

Table 2 about here

From October 2016 - January 2017, the author was joined by a university colleague from the UK, who had come to Oman on her sabbatical leave. Early in this visit it was decided that, together, they would build upon the author's pre-existing experience and knowledge of Oman's historical infrastructure, and spend the next four months intensively researching into the management of tourism at Oman's historical sites. Quickly, the planned study became focused and structured; and through discussions about theories of authenticity, Orientalism and the presentation of history, four broad research questions emerged:

1. How does the Omani government, and its agencies, manage perceptions of history among tourists in Oman?

2. What explanatory and contextual narratives are provided to tourists visiting historical sites and artefacts?

3. How do tourists perceive and understand these narratives, and integrate them into their experiences of visiting Oman?

4. How do tourism workers perceive and understand these narratives, and what do they think about tourists integrating such narratives into their experiences of visiting Oman? 
The subsequent fieldwork involved a multimethod ethnographic approach using participant observation, interviews and documentary research (see Brockmann, 2011; Lassiter, 2008, 2005; May \& Pattillo-McCoy, 2000), the goal of which was to achieve a Weberian verstehen (Weber, 2017, p. 20-23; 1964, p. 7) - i.e., an understanding of how sense is made of historical sites by tourists, and by those working in the tourism industry. The rationale for using this multimethod approach was that we were trying to understand the perceptions, understandings and experiences of those who visited Oman's historical sites, those who managed them, and those who worked at them. Using this methodology, the goal at the data analysis level was to identify perceptual and conceptual patterning among those we interviewed and observed.

Overall, we sought to achieve, as Weber (1964, p. 99) recommended, "adequacy at the level of meaning", such that we gained an understanding of how tourists and practitioners perceived and understood the sites. A key requirement of this methodological approach was that our analyses and findings should be understandable, and seem reasonable, to those interacting with the locations. We thus maintained an active and ongoing engagement with participants to ensure the meaningfulness of the analyses and findings to them. As part of the research, we communicated our findings back to the participants, who broadly agreed with our analyses of their actions and understandings.

Having a male and a female in a research partnership worked well in this case, with each gaining slightly different impressions and insights from the sites, and from interactions with those involved in the locations. Similarities, differences and contradictions in interpretations were explored through ongoing discussions between the researchers and with the participants. From the initial framing of the research questions onwards, this discursive element of the research was an integral process in the development of the analyses. Having a multi-gender team was advantageous in other ways - for instance, we found that the female researcher was better placed to approach and converse with female tourists and industry representatives.

\section{Research Structure and Activities}

The first stage of the research involved participant observation. Sometimes together and other times separately we visited the historical sites listed in Table 2. Some places were visited only a couple of times, but these provided context and insight for the ongoing development of 
the analysis. Other locations became the focus of our study; and we together repeatedly visited these spaces until we were satisfied that we had collaboratively achieved a broad verstehen, or understanding, that was adequate at the level of meaning experienced by tourists visiting these locations. The particular sites that were the focus of the research were visited at least five times, with six places visited more than twenty times (see Table 2). The average visit lasted about two hours. Most of the expeditions were pre-planned, though some were impromptu and opportunistic. Almost all the trips resulted in useful episodes of participant observation. Over time, through ongoing discussions between the researchers, and with fellow visitors, we were able to identify patterns in the perceptions, understandings and experiences of those involved with the sites. The fellow tourists we spoke to were of diverse backgrounds, with a balance of expatriate families already living in Oman, and visitors, predominantly from Western Europe and North America, with Germans, French and British particularly well-represented. There was a balance of genders among them, and most were middle aged.

The second stage of the fieldwork involved conversational and semi-structured interviews with those whose work required "front stage" contact with the visitors (Goffman, 1959, 1961). Reisinger and Steiner (2006) observed that the tourist experience is often constructed through the intermediation of tour guides, and in Oman this is true for many visitors. Most of the research in this phase thus focused on guides. However, we also interviewed other staff at forts and museums, including site receptionists, security personnel and gallery attendants. We were interested in the narratives practitioners expressed, and in their sense of the perception and adoption of these narratives by visitors to the sites. Most of the interviews were conducted in English, though some discussions with the staff in the forts took place in Arabic, with the tour guides and research assistants translating the conversations. Forty-three interviews were conducted in this phase, with each session typically lasting from half an hour to an hour. In terms of the participants who were interviewed during this period: seventeen were tour guides; twelve were site receptionists; three were security personnel; and five were gallery attendants. Some of the participants were interviewed more than once.

The third stage involved the participant observation of guided tours of museums and historical sites. This involved attending the tours, and holding informal conversations with the visitors and guides as the tours continued. Some of these tours were taken more than once. As part of our further engagement with those involved in Omani tourism, besides 
formal interviews with the tour guides and participant observation of the tours, the authors spent leisure time with the guides and their colleagues, engaging in informal conversations, eating together, and on occasions, staying at their homes with their families. The Omani tour guides involved in the research were predominantly men in their twenties and thirties; but we also toured with and interviewed a female guide in her forties. In all, we participated in twenty-one tours.

The fourth stage involved interviewing key informants, i.e., those who worked at the policymaking and managerial levels in the tourism industry, and who had a significant knowledge of it. These included representatives at the Ministry of Tourism, the Ministry of Heritage and Culture, the Ministry of Regional Municipalities and Water Resources, and the Ministry of Transport and Communications, along with museum directors and tourism academics who either had advisory roles, or were in charge of law enforcement, regulation or legislation. These people made decisions related to various aspects of heritage tourism development in Oman, involving the inclusion and crafting of particular presentations of cultural heritage in historical sites, tourism packages and promotional materials. Twelve such key informants were interviewed, with sessions usually lasting about an hour.

The fifth part of the research included reading through and discussing texts and documents relevant to the study, such as reviews posted on TripAdvisor (tripadvisor.com), and Lonely Planet Thorntree Forum (lonelyplanet.com). We used this discourse more as a confirmatory resource in line with Geertz's (1973) recommendation of using multiple sources of insight to achieve "thick description". In order to understand better the official view on certain issues, we also read through and discussed state documents such as the Omani constitution.

These five research approaches were interrelated and took place at the same time, with the data and insights we received from each feeding into and informing further data collection. As we were guided by constructivist principles, the analysis and patterning of concepts and themes developed as the research progressed (Manning, 1997). We integrated this ongoing analytical development with a form of snowballing, whereby, as the research proceeded, participants supplied further insights and contacts. (Patton, 1990). Snowballing like this helped us to access networks, which would have been difficult to reach any other way. 
During this process of participant observation, interviews, feedback to those involved, and ongoing discussions between the researchers, we were able to identify certain patterns in the perceptions, understandings and experiences of those involved with tourist sites in Oman. Doing so, we distinguished themes, which enabled us to analyse the management of these historical sites within the broader context of the political realities in Oman. Our findings can be checked for validity and rigour by further studies using the same or similar methodological approaches. Of course, the economy and society of Oman are changing rapidly, and future research in this field will reflect these changes; but subsequent studies will provide a useful standpoint from which to evaluate the significance, limitations and usefulness of this research.

In the following sections, we present our findings and analyses. Participants' views are incorporated, with some of them quoted to support and exemplify the patterns and themes we uncovered. The names of the research participants, and one of the castles, are anonymised.

\section{Presentation of the findings}

Oman's Forts - Historical sites without history

When they go to the castle, the impression, because each castle they have special story, so the story is very, very like, like a fairy tale. Fairy tale for the tourist...(TG1)

Three things were common to most of the castles we visited. Firstly, they had been renovated in the state programme of restoring many of Oman's forts and castles. Secondly, there was an almost complete absence of historical information provided at these places. Thirdly, there were usually extensive displays of sanitised cultural heritage at the sites. At the recently restored UNESCO World Heritage Site of Bahla Castle, the receptionists had poor English and no information about the history of the place. This lack of historical context was reflected at other locations. There were, however, minor exceptions to this. At Jibreen castle, a wooden sign gave some information about the founding of the complex. Here is the text in its entirety (see Appendix 4):

Jabreen Castle was built primarily by Imam Bil'arab bin Sultan Al Ya'rubi around 1091 AH/ 1680 AD when he moved his capital from Nizwa to Jabreen. Imam Bil'arab died at Jabreen 
in approximately 1692, and found eternal rest in a tomb inside the castle. Muhammad bin Nasr Al-Ghafiri resumed building activities and made alterations to the castle in the 12th century AH/ 18th century AD.

Likewise, in the entrance to Rustaq fort, there was a small board which mentioned that the Yaruba dynasty had founded the castle and evicted the Portuguese from Oman, but no information was provided about the events, sieges, wars and politics that the castle itself had been involved in up to the late twentieth century. Meanwhile the information given at Nakhal fort was even more scant. Here is the full text of the sign at the site (see Appendix 5):

Nakhal fort, which overlooks vast palm orchards, is spectacular. It is believed to date back to the pre-Islamic era and is dramatically located at the edge of the Jabal Akhdar mountains in northwest Oman. The high location of the fort gave it a distinct and unique appearance and, unlike others in Oman: this fort looks like a monument carried by a gigantic hand above its surroundings. Nearby is a beautiful oasis and hot spring. While the source has been enclosed solely for viewing, the shaded rest area complete with playground makes for a welcome break.

In this case, the only historical information given was that the site may date back to the preIslamic era. Overwhelmingly, however, Oman's historical sites were presented without any history at all. Instead, some of the castles had displays of aspects of Oman's cultural heritage, which were sanitised of their historical, economic, military and political contexts. A good example of this was the large and impressive display of cooking utensils in the old kitchen at Al Hazm castle (see Appendix 6). Huge pots, ladles, knives and other objects hung from the ceiling or were displayed on ancient tables and cutting boards. The presentation was obviously intended to display the wealth and fine-living of the family who had owned the fort; and the accompanying audio guide evoked the noise, smoke and industry of the kitchen, and its key role in the life of the household. The presentation was interesting and charming, as we made our way through the castle, and it fed into the definition of Al Hazm as an exotic, enchanting palace. In reality, of course, the castle's primary role had been as a military establishment, which had been very much involved in bloody regional and tribal conflicts up until the second half of the twentieth century. Work in the kitchen of such an establishment would have been extremely hot and exhausting, and characterised by inequality, exploitation and very probably slavery. Instead of presentations on the historical, political and military 
role of the castle, and the brutality of domestic labour within it, however, the visitor encountered a succession of displays of sanitised cultural heritage, of which the kitchen was but one.

\section{The case of Nizwa fort}

Nizwa Fort is the highest profile castle in Oman. It is often featured in tourist-oriented promotional materials and media, and it consistently receives more tourists than any other castle. In 2013, the total number of visitors to the site was 97,608, and in 2015, it was 100,899 (National Centre for Statistics and Information, 2018). Nizwa Fort was the political and military headquarters of various Yaruba Imams, the figureheads of the interior tribes, who - as we have already discussed - led military campaigns against the Sultans. The castle played a key role in the Jebel Akhdar War (1954-1959), during which it was pounded by British jets, which partly destroyed its massive outside wall (see Dye, 2008). During the renovation of the site in the 1980s (Hegazy, 2014), the hole in the wall was repaired, leaving no evidence of damage. The castle's violent history has thereby been concealed from tourists, with no information given about its political and military past.

This plastering over of the past is typical of the rest of Oman's ancient castles and forts. During our research, we reviewed old photographs and descriptions of the sites. They depicted derelict and damaged structures, which clearly embodied the violence and disorder of their times, and indeed of the history of Oman generally. With the restoration of these structures from the 1970s onwards, all damage was carefully concealed, leaving grand complexes, sterilised of evidence of their violent and disorderly pasts. Structurally the restored buildings are undoubtedly magnificent, evidently embodying tourist expectations of what an "Arab castle" looks like. Importantly, however, the restoration has left the structures looking both old and new at the same time - old in the sense that they are clearly ancient structures, but new in that they are pristine and sanitised in appearance. The fact that they are both ancient and new facilitates the exoticisation of the tourist experience. It means that those who enter the sites feel they are walking back in time to when the castles were new. Without damage, decrepitude or evidence of the miseries of conflict, the sanitised structures are now perfect stages for the presentation of Orientalised fantasy experiences, which distract visitors from questions about the political history of the castles, and of Oman. 
At Nizwa, as with many of the sites, history is obscured by using specific forms of sanitised cultural heritage - with displays of dates-storing and processing, water management systems, dowry jewellery, traditional costumes and frankincense-growing and distribution. The selfOrientalising display of such aspects of cultural heritage works as an exotic veil over the castle's violent history - charming visitors, while deflecting their interests and gaze away from questions of politics and military conflict. The exotic veil, the presentation of sanitised cultural heritage in place of history, is sustained in a powerful self-Orientalising way at many of these military sites - Jibreen, Nizwa, Nakhal, Rustaq, Al Hazm and Al Ain.

Tourists at Nizwa Castle were enchanted by what they saw, heard and smelled:

Perfect, perfect. Just what I dreamed of. You can imagine the people here going about their everyday business .. it must have been a magical time. Imagine living here back then .. it must have been amazing.. I sat in that room with the beautiful cushions and it was so peaceful. Spiritual, really. (American woman in her mid-sixties)

You really get a feel of what it was like for the people living here. They obviously were very civilised - more than us. It's a stunning place, isn't it, and the views from the top take your breath away. I just love Oman. (British man in his forties).

These two conversations took place within the walls of Nizwa castle, and were typical of visitors, not just to that particular site, but to other military structures throughout the country. Three words came up repeatedly in such conversations, which indicated that the sanitised staging of the restored castle, and the weaving of the exotic veil, had worked well: "magical", "peaceful" and "civilised". The word "spiritual" was also often heard. For a military complex, with a recent history of violence and political agitation to be described in these terms is remarkable. The staging and weaving of the exotic veil were thus done with great effect, with the frankincense, handiworks, costumes and the mountain-settings framing the perceptions, experiences and understandings of visiting tourists, who left feeling enchanted, but no wiser about the history of the site they had just visited.

\section{Al-Ain castle - unpicking the veil}


Al Ain is one of the most popular castles in Oman, and is on many tourist itineraries. We visited the site six times, and had long conversations with "Mohammed" (anonymised name), the receptionist and guide on each occasion. When we entered the castle for the first time, he welcomed us warmly and presented us with hand held audio guides, which, he said, visitors generally enjoyed using. We explored the castle first without the audio guide, so as to naively examine the space. Then, on our next visit, we inspected the site using the audio guide.

The fortress was well signposted, with each room named in terms of its traditional function. There were rooms for guests, for children, for guards; the Imam's suite of rooms, the madrasa (Islamic teaching room), and there was a small school for the Imam's children, with particular attention given to the presentation of the school for girls. One of the tour guides told us about the encounters there:

Tourists are usually interested to know more about where the rooms for females and for males are; and they often ask about how they live. (TG1)

The overall narrative of the castle, supported by plentiful cultural accoutrements and audiovisual presentations, was that here was the grand residence for the Imam's family. The combination of beautifully presented traditional rooms and artefacts, music, charming fantastical stories and audio-visual presentations was designed to immerse the visitor in an experience of "authentic" Oman - one of Imams, luxurious living, and educated, tolerant people.

Oman is well known for its long tradition of black magic and jinns, or genies. Notably, in the castle there was the "jinn's chamber", where a genie allegedly resided. Upon entering the room we were met with mysterious sounds and lights, which rendered the visit very entertaining and charming. There was also an enchanting story told on the audio guide about why it was called the jinn's room.

Also inside Al Ain castle, there was a prison, where a gruesome display showed how inmates were once tortured. Nothing was given its political or historical context. Who were the prisoners? Were they members of a rival tribe? What was the Imam's political/ military role? Who were his rivals? Who did he fight against? One of the highlights of the castle was the grand rotunda, where a large number of ancient, colossal cannons were beautifully displayed 
(Figure 3). Again no historical context was given. Who were the cannons shooting at? Instead the tourist was presented with displays of sanitised cultural heritage elaborating the domestic life of a rich and powerful family in $18^{\text {th }}$ century Oman, while the electronic tour-phone guided one through the rooms, weaving stories of the Imam, genies (jinn), the plight of prisoners, and the luxurious baths.

Figure 3 about here

Here, then, was a beautifully presented historical site with literally no history. Instead, idealised and sanitised presentations of cultural heritage had been crafted to deflect tourist perceptions and attention away from political and military history at every point - even in the cannon room. The castle infrastructure lent itself well to this Orientalised narrative, and the supporting audio guide was well-produced and coherent. The stories were entertaining and there was good use of humour throughout. As was the case with Nizwa, tourists we spoke to left thoroughly enchanted by their trip to Al Ain fort, but departed no wiser about the controversial history of the site.

As we repeated our visits and developed a friendly rapport with Mohammed, the receptionist and main guide, he began to express bitterness about the presentation of the castle, and identified lots of social problems in the surrounding area. He sadly observed that many people in the Interior were poor, due to state corruption. When we asked about disability access to the castle, he said that they had received the funds to build this, but the money had suddenly disappeared. Again, he put this down to corruption. This theme was reflected among many of the tour guides we spoke to.

Mohammed was unhappy with how the things were presented at the castle, and on the audio guide. He singled out the torture exhibition of the prison, saying it was not in the spirit of Ibadi Islam to treat prisoners in that way - drawing similarities between this presentation and how Islam is presented in the media in the West. He criticised the way features of the castle had been "spiced-up" to make them more interesting to visitors. He was all for talking about Oman's heritage, but was not in favour of exoticising it for the sake of tourists and tourism. For Mohammed, this was not simply a matter of facilitating "easy" consumption through 
simplification of historical complexity, but of presenting a dream-like fantasy, rather than the brute reality of the castle's military history (Bryce, 2012).

Mohammed talked of the recent history of the castle; of how it had been used as a base for British troops in their military campaign against the Sultan's enemies, who operated in the mountains during the Jebel al Akhdar war. He showed us old video footage of the castle in a ruined, war-ravaged state. The film showing the derelict castle was not presented to visitors. We had first met Mohammed in his front-stage incarnation (Goffman, 1959, 1961), where he helped us along in the Orientalisation of the castle, offering dates and kahwa (Omani traditional coffee with cardamom), traditional Omani hospitality, encouraging us to immerse ourselves in the cultural heritage presentations provided. However, through questioning and engagement with him over several visits, the conversations shifted backstage - behind the veil - where he presented a startlingly different definition of the castle and its presentation - one not of exotic cultural heritage, but of oppression, military might and tribal and state violence. The same transition happened with many of our industry interviewees. We met them in the front-stage tourist sphere, in front of the veil, where their job was to stage authenticity through self-Orientalisation - but as our relationships deepened, the settings, dress and definitions of the historical sites and their presentations changed markedly as the veil was lifted.

\section{Museums, ports and slavery}

As mentioned, the museum at Nizwa castle presented no meaningful history, only a narrow and sanitised cultural heritage. Ironically, perhaps, the exclusion of history and its replacement with sanitised presentations of cultural heritage was at its most complete in the National Museum of Oman, the repository of many of the country's most significant historical artefacts. Here weapons were displayed without mentioning tribal conflicts or civil wars; Omani ships, or dhows, were displayed as artefacts of the "great maritime empire", without once mentioning their role in the slave trade. The narrative was of an enlightened, powerful, maritime nation with a rich culture, with displays and texts at each of the exhibits carefully - and successfully - crafted to enhance the touristic experience of authenticity. Cumulatively, this wove an Orientalist spell on the observer, reinforcing the exoticness and alterity of the culture-rich space, and thereby of the country as a whole (see Korpela, 2010). 
Miniature models of the major castles were exhibited without any mention of their use as military establishments, or the wars they were involved in.

An exotic veil was thereby drawn over each historical artefact. The combination of staged authenticity with exaggerated Orientalism charmed the visitor, who was encouraged at every step to see Oman as a unified, exotic, culture-rich place. Within this experiential space, questions of conflict, contradiction, politics did not arise; and tourists left the museum enchanted with the unique otherworldly heritage of the "country" and "people" of Oman. At the very heart of the presentation of Omani history - the National Museum - history was excluded, and a strongly Orientalised presentation of cultural heritage put in its place.

One of our key informants concerning the National Museum was a highly-educated and eloquent Omani senior government executive, who provided us with interesting insights into the self-Orientalisation of Oman, and the replacement of history with sanitised cultural heritage at historical sites, including the National Museum:

When we looked at the underlying philosophical principles of museography plans internationally and regionally, we did not foresee undertaking traditional paths. At the national historic museum in Moscow for example, the emphasis is on chronological timeline with the focus on the achievements of that nation under a particular ruler. So it has a particular hierarchical reading of history of that nation. And we did not foresee this approach. Then there was another approach where you have a chronological approach in the broader sense starting from the earliest period to the most recent. And we did not foresee that either. We have decided to go ... to adopt a thematic approach whereby we combine thematic links in the chronological context or vice versa. The reason for that was to create a thought provoking experience, an experience that would sound and feel on you, even to local residents, so we tried to present a history of the cultural heritage of Oman from that aspect.

The Ministries thus pursued a policy of intentionally displacing history with Orientalised cultural heritage in the presentation of historical sites and artefacts.

Besides the National Museum, two of the most popular tourist hot-spots, the ports of Muttrah and Sur, are historically controversial, as they were key hubs in the slave trade (Alpers \& Hopper, 2017; Suzuki, 2017; Al Ghailani, 2015). This was not mentioned in any tourism 
information or display at the sites, and every day foreign tourists flocked to these locations completely oblivious to their recent slaving roles. Instead, at Muttrah port, thousands of tourists shuffled around the narrow streets of the traditional market, or souq, breathing frankincense-laden air and picking out traditional Omani handicrafts, jewellery, head-ware and veils - oblivious to the fact that this, relatively recently, had been a locus of the slave trade (see Clarence-Smith, 2013). They were also oblivious to the fact that most of the selfOrientalising Omanis in the enchanting souq stores themselves shopped at thoroughly modern supermarkets in Muscat, such as Lulu or Carrefour.

Slavery is taboo in Oman, as it highlights ethnically-based structural inequalities that persist today, and it contradicts the liberal modern ethos of the Sultanic order. Any mention of it has been sterilised from civic life, excluded from public narratives or presentations of history, particularly those to tourists. Indeed, in one interview with a senior key informant from the Ministry of Tourism, when we asked about slavery, we were told in no uncertain terms,

We all live together in peace here in Oman. We are all Omanis. There is no need to dig up stuff like slavery, as it is all forgotten now.

We asked about slavery again in interviews at a parallel institution, the Ministry of Heritage and Culture. Again, we received the answer - "we are all Omanis now". We were also told by officials at the ministry that they were afraid to speak about slavery, as mentioning it was inappropriate - even illegal. One informant claimed he could end up in prison for referring to it, particularly in written mode. As the interviews in the ministries proceeded, it became increasingly apparent that both the Ministry of Tourism and the Ministry of Heritage and Culture were intentionally keeping any word about slavery from presentations of, and narratives about, historical artefacts and sites. They were also deeply cautious about being seen to be doing so.

When we discussed the issue of slavery with one of the tour guides, he said that, at home, some former slave families still have a contract with their former owners, and that this contract is still respected. For instance, if members of former slave families wish to move out of the country, change religion, get married or buy property, their former masters have to approve the decision. It is also the custom that when there is a major celebration in the home 
of former masters, it is the duty of former slaves to attend and to be presented as slaves, as it enhances the noble status of the family.

However, Article 12 of the Omani constitution states,

Collaboration and compassion are intimate bonds amongst the Citizens. The reinforcement of the national unity is a duty. The State shall prevent anything that might lead to division, discord or disruption of the national unity.

The imperative for national unity and equality thus appears to hold sway in institutional and public discourse. However, it is apparent that deeply seated norms, customs and vernacular knowledge prevail in the confines of Oman's homes, families and private spheres; and it is clear that in localised situations they can and do take precedence over state regulations.

Article 12 of the Omani Constitution also pronounces the following:

The family is the basis of the society and the Law regulates the means for protecting it, ...

In interviews, we were repeatedly reminded that Omanis were living in the time of "Sultanic renaissance" and "national rebirth". Citizens are officially equal when it comes to international human rights and the state constitution, but local mores continue to hold sway in the relationships between the different parts of Omani societies. The Omanis we interviewed knew full well that they were not equal, but would not discuss this in public. In the public sphere, they presented themselves and their country in terms of being one nation, with all citizens being equal. This was the narrative required and presented by government and its agents in the tourism industry. However, the reality of recent Omani history has been of divisions, violence and inequalities that persist to this day. Because the discussion of history inevitably highlights present day division, potential violence and inequalities, the state has engaged in a partially successful campaign of defining anything pre-1970 as being of the dark ages, and therefore irrelevant.

Castles are a big part of Oman's tourism capital, and its pull on international visitors. Given the country's violent, sectarian and oppressive history, the government of Oman has faced the problem of how to present history at these sites. The solution pursued by the state and its 
agents has been to uphold an exotic veil of idealised cultural heritage to obscure history altogether. This has been implemented throughout the tourist industry in the most systematic and thorough ways. The war-damaged, derelict castles of forty years ago have been rebuilt and restored, and are unquestionably spectacular. Within them, carefully crafted versions of traditional cultural heritage are used to veil tourist perceptions from Oman's violent and divisive history. Images of restored castles and idealised cultural heritage are effective in promoting a highly Orientalised social construction of Oman to potential visitors, and in exoticising the tourist experience during their visits. Tourists are thus attracted to an exotic self-Orientalising Oman, and they visit and leave the country charmed and impressed, with no inkling of its violent history and persistent political divisions and social inequalities. This is exactly what the Ministry of Tourism and the Ministry of Heritage and Culture want, and in economic terms the exotic veil has worked well as a policy.

\section{Behind the veil - discussions with the tour guides}

Tour guides are key agents in promoting the narratives, which sustain the exotic veil over history in Oman (see Dahles, 2002). Their explanations and stories at historical sites are not politically neutral, but are accountable to the policies managed and sustained by the state. The guides we interviewed were highly sensitive to the dominant hegemonic imperatives, and the need to compound the Orientalist expectations of the visitors. They emphasised that visitor interest tended to focus on the culture, particularly on trying to find cultural differences which supported the Orientalised binary between "East" and "West". Although there were occasional questions about history, these were quickly defused or deflected. The main questions tourists asked related to culture and family life, and relations between males and females. The interactions between the tour guides and the visitors thus involved the cocreation of the exotic, other, Orientalised Oman:

Okay, they [tourists] will ask about the weddings, if there's still arranged marriage here or now is a boy have to find the girl. (TG3, male)

Further, another male tour guide said that almost every tourist asked the following question, 
Tour guides sometimes commented that they found some of the questions to be rather ridiculing their culture. As one of them mentioned:

I really do not like when they ask me how many brothers and sisters I have and when I tell them, they start giggling and laughing at me, or in the best case they say "wow". I find it very rude to make so much fun out of my family. (TG3, male)

Sometimes tourists try to elaborate the binary cultural differences,

They ask sometimes a very stupid question you know. If you're married can you kiss your wife in front of your parents? (TG2, male)

Omani tour guides were frustrated by a number of expatriates living in Oman who were also operating as local tour guides. These expats did not need to pass exams, but only to register with the Ministry of Tourism, whilst local guides had to pass an examination and a language test. Omani tour guides worked mostly for travel agents, whilst expatriate guides were predominantly freelancers, thus enjoying more freedom than the local guides. The Omanis said that expatriate tour guides exoticised cultural differences and binaries even more than they did, often making exaggerated observations at the expense of the locals, to entertain and enchant the tourists. We went to one of these tours, and the gentle mocking of the "culturally different" locals was a feature throughout. When they heard it, the Omani tour guides felt that their culture, values and lifestyle were being misrepresented.

And over that they're not giving the right information to the guest because we have some places ladies they cover and some of them don't cover you know. They're saying, you know, because her husband he told she must, she will be covered, but this is not true. I heard it. (TG3, male)

Whereas such statements were uncritically and enthusiastically received by most tourists, they were resented by the Omani guides. Although both locals and expatriates were in the business of Orientalising Oman's history and culture, it was felt that the expatriates did so in a negative way that portrayed Omanis not just as different, but as inferior to the tourists: 
But some of them they give wrong information about my country. I feel nervous, I feel angry. I want to stop them but I respect the tourist but sometime if I get offense I stop them. (TGI, female)

So he [expat tour guide] has say [sic] something very bad about the local people. They should respect the people in this area. (TG1, female)

Trivialising local cultures as odd, strange, exotic, charming, backward or traditional are common Orientalising methods in tourism. Encouraged by the highly exoticised promotional material and media, tourists come to Oman expecting and seeking these narratives about alterity; and tour guides see it as part of their roles to provide and embody such characterisations, even though these contradict their actual lifestyles and opinions. The Orientalisation of Oman and its culture is thus arguably an act of co-creation. Visitors gasp, chuckle and wow at the vagaries of Omani cultural heritage, as the tour guides (both Omani and expatriate) obscure a violent history, a police state, censorship, corruption and social inequality, by weaving a fragrant veil of Orientalist spells around the visitors.

As we have noted above, tourism practitioners can find themselves in the position of having to resist, ameliorate or become complicit in the obscuring of their own history. Local tour guides invariably dress in traditional costume, wear intoxicating oud perfume to enhance the sensory Orientalist experience, and tell stories of jinns, great empires and, above all, of the great Sultan Qaboos. Thus, on one side, the guides both embody and act out the state policy of self-Orientalisation. Meanwhile, the type of tourists who employ the services of a tour guide, are usually highly receptive to this - they actively want the exotic, and the charming Orientalist narratives and discourse.

This point was reflected by TG1, who observed that the exoticisation of Omani culture involves "talking the language of the tourists, this is what they want to hear". Complex historical legacies are thus simplified for commercial and operational reasons, and these characterisations resonate with particular civilisational assumptions consumers carry with them. According to Guattari (1989) the process of experience creation is often masked by slogans invoking certain states of mind; for instance, reinforcing and normalising binary distinctions between East (Islam) and West (European Christendom). Guattari (1989) further argues that only if subjects are critically alert to discourse manipulation can their sense of 
meaning of the heritage sites be truly co-creational. Thus, according to this view, the selective use, interpretation and commodification of the past becomes less of a co-creation between the consumer, tour guide and the site; and more of a power-led exercise, enacting an illusion of co-creation.

The Orientalised narrative sustained by the Ministry of Tourism is coherent and successful in excluding history, while providing "authentic" experiences for visitors. However, contradictions remain that threaten the narrative's coherence and sustainability. Many of the tour guides are relatively young, urban, Net-savvy and globalised in culture; and they lead recognisably Western, modern lifestyles. From our interviews it became apparent that the disjunctures between their lives of, for instance, drinking in bars and going to Muscat rock concerts, and their work presentations of traditional authenticity, meant they were acting-out an idealised, sanitised version of what it was to be "Omani". In their staging of authenticity for tourists, many thus experienced strong existential feelings of inauthenticity to themselves and the modern urban life of which they were a part. As features of this staged authenticity and the weaving of Orientalism, they sanitised history from their presentations and from replies to queries. This exacerbated the existential contradictions embedded in their identity.

In a Nizwa hotel, we met two off-duty tour guides in Western clothes, drinking beer and smoking cigarettes. They had carefully positioned themselves out of sight, in case any of their tour participants ventured into the same bar. In Goffman's (1961) terms, they were spatially and symbolically backstage. In our first encounter with them, we explained that we were researchers; we played pool with them, and asked them a number of questions. After a friendly discussion, one of us asked if they ever mentioned slavery in their presentations. They went quiet. One of them eventually replied that slavery is not something that anyone talks about.

For tour guides, the existential contradictions sustained by the Sultanic hegemony are keenly felt, and lead to feelings of powerlessness and betrayal of their identities. Tribal allegiance is a foundational feature of Omani society, with tribal conflicts and collective injustices within living memories discussed in homes and villages. As we were told by one of the research participants: "every family has one 'uncle' who knows about the history. We speak about it in the family". Further we were told that in school, there is only "general history", nothing about the detailed political/ military history of Oman. History is private, not public - a subject 
which is only discussed at home. As the research proceeded, it became apparent that this is a history that may be lost over the next few generations.

The past is thus obscured by the state, with a Sultanic, history-less, unity imposed upon the very people whose job it is to enlighten others about historical sites. Although the exotic veil, the front-stage presentation of authentic Orientalism, is overwhelmingly sustained, our research allowed us backstage, behind the veil, into the lives of those whose job it was to present it. Here the views on the required performance were strongly expressed. The castle receptionist mentioned before, whose job was to present a traditional Omani welcome and explain the electronic hand-held tour guide device, was clearly angry at the state-imposed narratives and presentations at the site. He complained that parts of the staging in particular rooms were simply made up for tourist consumption, and misrepresented their original usage and contextual history. Key in this, he made the point (reflected in other backstage interviews) that the tensions and contradictions that gave rise to the Jebel al Akhdar war were still there, and could reappear if the Sultanic-imposed unity were to weaken.

The government of Oman is not as unified as people are encouraged to believe. There are tensions between the Ministry of Tourism and the Ministry of Heritage and Culture, for instance. The Ministry of Heritage and Culture is responsible for archaeological activity in the Sultanate and it was this organisation that oversaw the restoration of many of the castles. The complexes were then passed over to the Ministry of Tourism for marketing; and the subsequent exclusion of history from the site narratives has caused tensions with those at that Ministry of Heritage and Culture who can clearly see the sterilisation of Oman's past for touristic purposes. With tourism being promoted as a key strategic industry in the diversification of Oman away from petrochemicals, the Ministry of Tourism has been able to sustain this policy, along with the support of conservative elements within the government who wish the narrative of post 1970 unity and equality to prevail seamlessly from the citizenship through to visiting tourists.

\section{Discussion}

The aim of this study was to understand how history is treated in tourist settings in Oman, and to reveal the reasons behind the shielding of visitors from history via a form of stateimposed self-Orientalism. Tourists were visiting sites like Bahla fort with little historical 
information. Many left enchanted, but some later felt confused about what they had seen, and expressed this in discussions on sites such as TripAdvisor. For some, it seemed that authentic experiences and intoxicating Orientalism were not enough, and they asked, “Where's the history?" This question is key to the whole issue of historical sites in Oman, for without adequate contextualisation, visitors are unable to understand what they are looking at. Of course, most tourists we spoke to were satisfied with their experiences at the sites, enthusing about the beauty and charm of them - the exotic veil had done its job. However, for a minority, the Orientalist enchantment left them intellectually dissatisfied.

For tour guides and site receptionists weaving authenticity and Orientalism, the denial of history is an existential issue, as it renders them complicit in the suppression of their own identity. This is a major issue for the development of Oman as a country, and raises the question of how long history can be sterilised from civic and touristic discourse in the name of Sultanic unity.

Weber's (1978) ideas encourage us to understand and explain (verstehen and erklärung) the reasons why institutions, dependent upon the unifying figure of the Sultan, seek to glorify post-1970 history, and to underplay, censor or exclude much of the time before his accession. We found both internal and external reasons for state sanctioned histories. From the internal side, state institutions have the power and authority to do this, as - for all its avowed tolerance - Oman is an autocratic state with no free press. History, then, is crafted, legitimised and enforced by the state in its schools, newspapers, media and universities. State-censored history thus prevails in Oman from the level of the citizenship, through to universities and into the ministries. If mentioned at all, the civil wars are cast as troubled steps on the path to unified modernity; the blood feuds and tribal wars are glossed over; and the slave trade is excluded from discourse in all public arenas, though cautiously discussed in the privacy of family homes.

Although imposing an exotic veil of self-Orientalism is an effective management strategy for obscuring history in the short term, it suppresses hard contradictions among tourists and citizens alike - and for the country as a whole. This may not be sustainable. With economic development, an urban middle class has emerged, globalised in its outlook, moving rapidly away from the traditional values and norms that characterised life in the Sultanate only twenty years ago. In spite of its economic and social development to date, the troubled 
history of the country sustains stressors, divisions and inequities that are keenly felt and retain their potential for disruption and conflict. Obscuring history in the name of Sultanic unity in a time of huge cultural change, and a high proportion of young people, means that these contradictions are exacerbated. If social and political developments are to feed into Oman's now faltering economic development, the obscuring of history should give way to open debate about it, and of the contradictions and inequities it sustains. For Oman, moving away from an exotic veil over the past to a more historically grounded visitor experience will mean that those involved in the growing tourist industry will be better able to resolve the contradictions between their work and their identity, and reclaim their history and identity in their interactions with tourists. They may even reclaim a cultural heritage that is less idealised and politicised.

\section{Conclusion}

The conceptual development and findings of this study can help us understand how and why some national governments seek to manage and control tourist-oriented narratives about historic sites and artefacts. In this paper, we have examined a particular method in the management and control of historical sites in Oman, which we characterise as the use of an exotic veil - the obscuring of history through self-Orientalisation and sanitised presentations of cultural heritage. The identification of this method of political censorship raises the question of its transferability - in other words, is the exotic veil also used in other countries?

Although government tourism departments in other parts of the world may encourage selfOrientalisation in promotional materials and among practitioners, in most cases this is not done to conceal history, but merely to encourage tourism to those countries. Government agencies may certainly encourage self-Orientalisation, but not require it. This is arguably the case in the management of tourism in places such as Malaysia and India (see, for instance, Kerrigan, Shivanandan \& Hede, 2012). In Thailand, self-Orientalisation is certainly widespread, though it is not imposed, except arguably in the hill-tribe areas, where local economies depend upon displays of exotic authenticity (Cohen, 1989). In these areas, tourists are presented with displays of exotic cultural heritage, while the violent and insecure recent history of the hill tribes is obscured (Latt \& Roth, 2015; Wittayapak, 2008). 
In some states, political elites sustain their power through suppressing division and dissent. In certain Gulf Arab countries, for instance, post-independence unity is actively imposed by the state (Hanieh, 2016). As Cooke (2014) observed, this is reflected in the requirement to wear uniform "national dress" at work and in public life. Such displays of unity, however, hide diversity and division. The political legacies of such countries' histories are deeply controversial and divisive. The history of the region up until independence was of colonial hegemony, tribal rivalries, confessional tensions and the persistence of slavery, which was only officially banned in these countries in the 1970s (see Cooper, 2013).

As Hanieh, (2016) highlights, these states are usually politically and economically dominated by one clan, which typically controls and exploits the country's petrochemical wealth. The persistent dominance of these families is widely resented among those tribes that lost out in the post-independence settlements; and among former slave families, which continue to experience exploitation and discrimination (see Alpers, \& Hopper, 2017; Alsudairi \& Abusharaf, 2015). In such countries it does appear that the carefully crafted governmentsustained exotic veil distracts visitors from the region's recent history of tribal rivalries and slavery. Highly Orientalised images and sounds are used in promotional media for Gulf countries' tourist industries, and exoticised displays of cultural heritage await visitors to the region's museums and historical sites (see Stephenson, 2014). This is true in Bahrain, where the exotic veil obscures an explosive historically-rooted political gulf between the majority Shia population and the Sunni ruling family (Gengler, 2014). In Vision 2030, Saudi Arabia is seeking to diversify into international tourism (Thompson, 2017). Given the country's recent history of war, tribal rivalry, confessional violence and political and economic domination by the House of Saud, it will be interesting to see how the government manages the problematic question of history, and presents its numerous historical sites to tourists.

There is much future research to be done, then, on the management and control of history in tourism around the world. Whereas, the exotic veil appears to be a feature of Gulf states other than Oman, further research on particular countries in the region is needed to verify this, and to refine and develop this conceptual approach. Certainly, other countries further afield appear to use imposed self-Orientalisation and cultural heritage in similar ways; and it seems likely that future researchers will find elements of the exotic veil in the management of tourism in countries such as Myanmar and China. 
Finally, this is a study of the management of tourism, or, to be more specific, the management of history in tourism. What tourism management lessons are to be learned from this study? The first is that those in government in certain states have clearly identified their own history as a threat, and decided that it must be carefully contained and managed in tourism activities and materials. With the advent of social media, such governments perceive (perhaps rightly) that history has become even more of a threat, as discussions of wars, massacres and slavery can quickly become amplified and result in political criticism of the ruling elites, and damage the tourist brand of the country. In order to deal with this problem, such governments have developed promotional and operational tourism policies that enable the economy to benefit from mass tourism while keeping history hidden. The development of the exotic veil as a policy is arguably a creative and effective response to perceived political threats posed by a problematic past and historically-rooted social problems. Where the policy first originated, and who developed it are fascinating questions, which further researchers may wish to explore. At the management research level these questions raise issues of agency, decision-making and contingency, which again are interesting areas in the development of this research theme.

In line with Weber's erklärung, which seeks to understand the laws and regulations which guide the process of reaching "adequacy at the level of meaning" (Weber, 1964, p. 99) it is important to understand the external context, i.e. "the context of the context" (Askegaard \& Linnet, 2011, p. 396) in which history is silenced in presentations to tourists and visitors. Those dictating policy in government ministries in Oman are conscious that their country borders neighbours with troubled reputations (Lewis, 2015): Yemen, where a vicious civil war is now happening; and Saudi Arabia, where human rights are problematic (Wald, 2018). With recent violent disorder in Lebanon, Egypt, Tunisia, Turkey, Syria and Iraq, Oman understandably - is seeking to distance itself from the instability and violence in the region. The fact that it too suffered from violent civil war and tribal conflict up until 1975 undermines the notion that Oman is different from other Arab countries - that it is stable and safe. All discussion of instability and conflict is therefore expunged from touristic discourse.

What we see from this study is that to date in Oman, and potentially in other countries as well, government managers and decision-makers have seen history as the problem, and the exotic veil as the solution. In terms of the future social, economic and political development of these countries, the case can be made, however, that the veil has become the problem. It is 
widely resented by those people who work in the tourism industry, who, on a daily basis, are obliged to misrepresent their history and their identities. It stifles real and arguably necessary social, political and economic change, and it has become a barrier to meaningful communication between tourists and locals. What then is the solution to the exotic veil? How should it itself be resolved? The answer is seemingly simple, but manifold in its implications - it should be removed, and the country's complex and fascinating history revealed to all. If this is done, the country will become understandable to tourists as having a past that is just as violent, complex and troubled as any European or American state - indeed, having a past that is just as violent and complex as visitors' own countries back home. Tourists will continue to come and amaze at the castles and historical sites, but this time they will be able to be more engaged with the realities of what they are seeing. With the removal of the exotic veil, tourism will not collapse, as the tourist infrastructure and support structure remain. With the drawing back of the veil, everybody benefits - except, perhaps, those who seek to stifle change. 


\section{References:}

Al-Azri, K. M. (2013). Social and gender inequality in Oman: the power of religious and political tradition. London: Routledge.

Al Ghailani, Y. A. (2015). British early intervention in the slave trade with Oman 1822-1873. History Research, 5(4), 225-238.

Alpers, E. A., \& Hopper, M. S. (2017). Speaking for themselves? Understanding African freed slave testimonies from the Western Indian Ocean, 1850s-1930s. The Journal of Indian Ocean World Studies, 1(1), 60-89.

Alsudairi, M., \& Abusharaf, R. M. (2015). Migration in pre- oil Qatar: a sketch. Studies in Ethnicity and Nationalism, 15(3), 511-5

Askegaard, S. and Linnet, J. (2011). Towards an epistemology of consumer culture theory: phenomenology and the context of context. Marketing Theory, 11(4), 381-404.

Ateljevic, I., \& Doorne, S. (2002). Representing New Zealand: tourism imagery and ideology. Annals of Tourism Research, 29(3), 648-667.

Berelson, B., \& Steiner, G. A. (1964). Human behaviour: an inventory of scientific findings. New York: Harcourt, Brace \& World.

Bloch, N. (2017). Barbarians in India. Tourism as moral contamination. Annals of Tourism Research, 62, 64-77.

Brockmann, M. (2011). Problematising short-term participant observation and multi-method ethnographic studies. Ethnography and Education, 6(2), 229-243.

Bryce, D. (2012) Turkey, tourism and interpellated 'Westernness': inscribing collective visitor subjectivity. Tourism Geographies, 14(3), 444-466.

Bryce, D., MacLaren, A. C., \& O'Gorman, K. D. (2013). Historicising consumption: 
Orientalist expectations of the Middle East. Consumption Markets \& Culture, 16(1), 45-64.

Clarence-Smith, W. G. (2013). The economics of the Indian Ocean and Red Sea slave trades in the $19^{\text {th }}$ century: an overview. In W. G. Clarence-Smith (Ed.). The Economics of the Indian Ocean Slave Trade in the Nineteenth Century. (pp. 1-21). London: Routledge.

Cohen, E. (1985). The tourist guide: the origins, structure and dynamics of a role. Annals of Tourism Research, 12 (1), 5-29.

Cohen, E. (1988). Authenticity and commoditization in tourism. Annals of Tourism Research, 15(3), 371-386.

Cohen, E. (1989). Primitive and remote: hill tribe trekking in Thailand. Annals of Tourism Research, 16(1), 30-61.

Cooke, M. (2014). Tribal modern: branding new nations in the Arab Gulf. Berkeley: University of California Press.

Cooper, N. (2013). City of gold, city of slaves: slavery and indentured servitude in Dubai. Journal of Strategic Security, 6(3), 65-71.

Dahles, H. (2002). The politics of tour guiding: image management in Indonesia. Annals of Tourism Research, 29(3), 783-800.

Derrida, J. (1978). Writing and difference. Chicago: University of Chicago Press.

Dye, P. (2008). The Jebel Akhdar War: The Royal Air Force in Oman. Royal Air Force Air Power Review, 11(3), 18-32.

Feighery, W. G. (2012). Tourism and self-Orientalism in Oman: a critical discourse analysis. Critical Discourse Studies, 9(3), 269-284.

Geertz, C. (1973). The Interpretation of Cultures. New York: Basic Book 
Gengler, J. (2014). Understanding sectarianism in the Persian Gulf. In L. G. Potter (Ed.). Sectarian politics in the Persian Gulf. (pp. 31-66.) Oxford, UK: Oxford University Press.

Goffman, E. (1961). Encounters. Indianapolis, IN: Bobbs-Merrill.

Goffman, E. (1959). The presentation of self in everyday life. New York: Doubleday.

Goulding, C., \& Domic, D. (2009). Heritage, identity and ideological manipulation: the case of Croatia. Annals of Tourism Research, 33(1), 85-102.

Guattari, F. (1989). Chaosmosis - an ethico-aesthetic paradigm. Bloomington, Indianapolis: Indiana University Press.

Hanieh, A. (2016). Capitalism and class in the Gulf Arab states. New York: Springer.

Hegazy, S. M. (2014). Conservation of Omani archaeological sites, Harat al-Bilad - a case study. International Journal of Arts \& Sciences, 7(4), 435-448.

Holguin, S. (2005). National Spain invites you: battlefield tourism during the Spanish Civil War. The American Historical Review, 110(5), 1399-1426.

Johnson, P. C. (2010). Writing liminal landscapes: the cosmopolitical gaze. Tourism Geographies, 12(4), 505-524.

Joyce, M. (1995) The Sultanate of Oman: a twentieth century history. Westport, Conn.: Praeger.

Kerrigan, F., Shivanandan, J., \& Hede, A.M. (2012). Nation branding: a critical appraisal of Incredible India. Journal of Macromarketing, 32(4), 319-327

Korpela, M. (2010). A postcolonial imagination? Westerners searching for authenticity in India. Journal of Ethnic and Migration Studies, 36(8), 1299-1315. 
Lassiter, L. E. (2005). Collaborative ethnography and public anthropology. Current Anthropology, 46(1), 83-106.

Lassiter, L. E. (2008). Moving past public anthropology and doing collaborative research. Annals of Anthropological Practice, 29(1), 70-86.

Latt, S., \& Roth, R. (2015). Agrarian change and ethnic politics: restructuring of Hmong and Shan labour and agricultural production in northern Thailand. Journal of Agrarian Change, $15(2), 220-238$.

Lewis, M. (2015). Oman and Yemen: so similar, so different.... Geocurrents. Retrieved from:

http://www.geocurrents.info/geopolitics/state-failure/oman-and-yemen-so-similar-so-

different

MacCannell, D. (1973). Staged authenticity: arrangements of social space in tourist settings. American Journal of Sociology, 79(3), 589-603.

MacCannell, D. (1976). The tourist. London: MacMillan.

Manning, K. (1997). Authenticity in constructivist inquiry: methodological considerations without prescription. Qualitative Inquiry, 3(1), 93-115.

May, R. A. B., \& Pattillo-McCoy, M. (2000). Do you see what I see? Examining a collaborative ethnography. Qualitative Inquiry, 6(1), 65-8.

Naef, P., \& Ploner, J. (2016). Tourism, conflict and contested heritage in former Yugoslavia. Journal of Tourism and Cultural Change, 14(3), 181-188.

National Centre for Statistics and Information (2018) Tourism data. Retrieved from: https://www.ncsi.gov.om/Pages/NCSI.aspx

Patton, M. (1990). Qualitative evaluation and research methods. Newbury Park, California: Sage. 
Phillips, W. (1971). Oman: a history. Beirut: Librairie du Liban.

Phillips, S. G., \& Hunt, J. S. (2017). 'Without Sultan Qaboos, we would be Yemen': The Renaissance narrative and the political settlement in Oman. Journal of International Development, 29(5), 645-660.

Podoshen, J. S. (2017). Trajectories in Holocaust tourism. Journal of Heritage Tourism, 12(4), 347-364.

Pritchard, A., \& Morgan, N. J. (2001) Culture, identity and tourism representation: marketing Cymru or Wales? Tourism Management, 22(2), 167-179.

Ram, Y., Björk, P., \& Weidenfeld, A. (2016). Authenticity and place attachment of major visitor attractions. Tourism Management, 52, 110-122.

Reisinger, Y., \& Steiner, C. (2006). Reconceptualising interpretation: the role of tour guides in authentic tourism. Current Issues in Tourism, 9(6), 481-498.

Risso, P. (1989). Oman and Muscat: an early modern history. London: Routledge

Rivera, L. A. (2008). Managing "spoiled" national identity: war, tourism, and memory in Croatia. American Sociological Review, 73(4), 613-634.

Said, E. (1978). Orientalism. London: Penguin.

Stephenson, M. L. (2014). Tourism, development and 'destination Dubai': cultural dilemmas and future challenges. Current Issues in Tourism, 17(8), 723-738.

Suzuki, H. (2017). Slave trade profiteers in the Western Indian Ocean. London: Palgrave Macmillan.

Thompson, M. C. (2017). 'Saudi Vision 2030': a viable response to youth aspirations and concerns? Asian Affairs, 48(2), 205-221. 
UNESCO (2018) Bahla fort. Retrieved at: https://whc.unesco.org/en/list/433

Valeri, M. (2009). Oman. Politics and society in the Qaboos-State. London: Hurst Publishers.

Valeri, M. (2010). High visibility, low profile: the Shi 'a in Oman under Sultan Qaboos.

International Journal of Middle East Studies, 42(2), 251-268.

Van der Duim, R. (2007). Tourismscapes: an actor-network perspective. Annals of Tourism Research, 34(4), 961-976.

Wald, E. R. (2018). Saudi, inc.: the Arabian Kingdom's pursuit of profit and power. London: Pegasus Books.

Weber, M. (2017). The methodology of the social sciences. London: Routledge.

Weber, M. (1978). Economy and society: an outline of interpretive sociology (Vol. 1). Berkeley: University of California Press.

Weber, M. (1964). The theory of social and economic organization. New York: The Free Press.

Wei, L., Qian, J., \& Sun, J. (2018). Self-Orientalism, joke-work and host-tourist relation. Annals of Tourism Research, 68, 89-99.

Wittayapak, C. (2008). History and geography of identifications related to resource conflicts and ethnic violence in Northern Thailand. Asia Pacific Viewpoint, 49(1), 111-127.

World Atlas (2018) Oman history timeline. Retrieved from: https://www.worldatlas.com/webimage/countrys/asia/oman/omtimeln.htm

Zeppel, H., \& Hall, C. M. (1991). Selling art and history: cultural heritage and tourism. The Journal of Tourism Studies, 2(1), 29-45. 